\title{
Human Resources Development for the Valuation of Property Investments in Nigeria: A Case for Practical-Based Training
}

\author{
Namnso Bassey Udoekanem \\ Department of Estate Management and Valuation \\ Federal University of Technology \\ Minna, Niger State, Nigeria
}

\begin{abstract}
This paper examines the development of human resources for the valuation of property investments in Nigeria. The paper argues that valuation of property investments is a highly practical exercise and should be taught as such to facilitate its understanding. Data for the study were obtained using structured questionnaires administered to graduating real estate students in a Federal University in Nigeria who have been taught property investment valuation courses for a period of four academic sessions, based on the minimum benchmark academic standards of the National Universities Commission. The study found that the students' overall level of understanding of the basic topics in property investment valuation was highest in the definition of property investments and lowest in hedonic modelling of property investment values. Analysis of Variance (ANOVA) in the level of understanding of the basic topics in property investment valuation between the male and female respondents produced an F-ratio of 0.53 at p-value greater than 0.05 . This implies that although there are differences in the level of understanding of the basic topics in property investment valuation between the male and female respondents, such differences are not significant statistically. The respondents strongly agreed that practical exercises in the field will facilitate understanding of property investment valuation. Similarly, they also agreed that lecturers with practical experience teach property investment valuation better. The paper recommends the introduction of more field exercises into the current property investment valuation curriculum of tertiary institutions in Nigeria as such initiative will facilitate the development of creative, innovative and practically-competent human resources for the accurate valuation of property investments in the country.
\end{abstract}

Key Words: Human Resources Development, Property Investment Valuation, Teaching, Learning, Nigeria 


\section{Introduction}

Human resources development is essential for the development of human capital. Human capital is one of the important factors necessary for the achievement of sustainable economic growth in any nation (Harbison, 1973; World Bank, 1974 and Peters, 2011). In particular, Harbison (1973) supported this assertion and concluded that:

"Human resources, not capital constitute the ultimate basis for the wealth of nations. Capital and natural resources are factors of production; human beings are the active agents who accumulate capital, exploit natural resources, build social, economic and political organizations and carry forward national development. Clearly, a country which is unable to develop skills and knowledge of its people and to utilize them effectively in the national economy will be unable to develop anything else".

Ake (1989) contended that the development of indigenous manpower to serve as the propelling force for natural growth and development is the key to Nigeria's socio-economic and political development. Also, human resources development is people-centred and as such captures the actual meaning of development (Grawboski and Shields, 1996). From economic standpoint, De Silva (1997) as adopted by Peters (2011) described human resources development as the accumulation of human capital and its effective utilization for the development of the economy. Peters (2011) argued that human resources development is the process of increasing the knowledge, skills and competences of the people in the workplace or in a country in general. He further emphasized that the concept of human resources development extends over several issues including population, education, health, nutrition, employment, sanitation, sports, culture, housing, communication, among others. Dawodu (n.d) believes that human resources development is the process of planning and controlling the way in which a person's performance and potentials are developed by training and educational development programmes. With a Human Development Index (HDI) of 0.511 (UNDP, 2010), the level of human resources development in Nigeria has been very low in recent times, particularly when compared with that of other developing countries as presented in Table 1.0. 
Table 1.0: Global Ranking of Nigeria and other selected Developing Countries based on the Human Development Index (HDI)

\begin{tabular}{lll}
\hline Country & $\begin{array}{l}\text { Human Development } \\
\text { Index }\end{array}$ & Global Ranking \\
\hline Angola & 0.564 & 143 \\
Barbados & 0.903 & 37 \\
Egypt & 0.703 & 123 \\
Gabon & 0.755 & 103 \\
Ghana & 0.526 & 152 \\
Malaysia & 0.829 & 66 \\
Nigeria & 0.511 & 150 \\
Seychelles & 0.846 & 57 \\
South Africa & 0.683 & 129 \\
South Korea & 0.937 & 26 \\
\hline
\end{tabular}

Source: UNDP (2010)

Experts in human resources development, including Ogunleye-Adetona (2010) and Peters (2011) have attributed Nigeria's poor human development status to uncontrolled population growth, poor leadership, poor manpower planning, poor funding of education at all levels in the country, religious factor and poverty, among others. The property valuation industry is an important sector of a nation's economy. The industry is primarily concerned with all activities relating to the valuation of all real property interests for all purposes. Property investment valuation is one of the core functions of the valuer the world over. Also, the valuer is the lead professional in any property valuation industry and requires adequate training for effective, efficient and sustainable operation of the industry (Millington, 1982).

\section{Human Resources Development for the Valuation of Property Investments in Nigeria}

The development of human resources for the valuation of property investments in Nigeria is done through three major institutions. These are universities, polytechnics and the Nigerian Institution of Estate Surveyors and Valuers (NIESV). While the universities and polytechnics offer formal training as tertiary educational institutions and award degrees and diplomas respectively, the Nigerian Institution of Estate Surveyors and Valuers (NIESV) is the professional body for the property valuation profession in Nigeria and offers professional training through Continuing Professional Development(CPD) workshops, symposia, conferences and professional examinations. However, human resources training for the 
valuation of property investments in the country is a subset of real estate education and is taught within the curriculum of Estate Management programmes of tertiary institutions in the country. The education and training of property investment valuers in Nigeria constitutes an important component of real estate education in the country. Real estate education and training in the country is based on the UK real estate education model in which the education of the property valuer is focused on five main subject areas namely; valuation, law, economics, building construction and planning. Property investment valuation in Nigeria is taught based on the fundamental precept derived from property investment valuation education in the UK in which property investment valuation is defined as the estimation of the future benefits to be enjoyed by the owner of a freehold or leasehold interest in land or property, expressing those future benefits in terms of present worth (Baum and Mackmin, 1989). On this note, this paper examines human resources development for the valuation of property investments in Nigeria and the need for practical-based training in the education and training of property valuers for impeccable valuation of property investments in the country.

\section{Methodology and Data}

Data for the study were obtained through structured questionnaires. A total of 131 structured questionnaires were administered to 500-level Bachelor of Technology (B.Tech) Degree students in the Department of Estate Management , Federal University of Technology, Minna, Niger State, Nigeria, selected through purposive sampling technique, out of which 84 were properly completed and returned, representing a response rate of 64\%.These students were selected because they have been taught property investment valuation as a course at various levels for about four academic sessions. Data collected for the study include the demographic characteristics of the respondents as presented in Table 2, respondents' opinions regarding their level of understanding of the basic topics in property investment valuation as well as their opinions on the teaching and learning of property investment valuation in the University as presented in Tables 3 and 4 respectively, among others. A 5-point Likert scale was used to determine the mean of the respondents' responses for each of the opinions. The respondents' opinions regarding their level of understanding of the basic topics in property investment valuation were analysed to determine their overall level of understanding. The points attached to the respondents' level of understanding are: Very Good (5); Good (4); Fair (3); Poor (2) and Very Poor (1). Also, their opinions on the teaching and learning of 
property investment valuation in the University were analysed to determine their consensus opinion and rank based on the respondents' mean response and Relative Importance Index (RII) respectively. Similarly, the weights attached to the respondents' opinions on the teaching and learning of property investment valuation in the University are: Strongly Agree (5); Agree (4); Undecided (3); Disagree (2) and strongly Disagree (1). The initial draft of the questionnaire was given to some senior academic colleagues for scrutiny to ensure the validity of the contents of the questionnaire. This resulted in the restructuring of the questionnaire to reflect the knowledge content required for the valuation of property investments in Nigeria. The reliability of the questionnaire, particularly its internal consistency was measured to ensure that the scale used for this study consistently reflect the construct it is measuring. This was done using the Cronbach's Alpha Reliability Coefficient. This Reliability Coefficient ranges between 0 and 1(Cronbach, 1951; Cronbach et al, 1972 and Cronbach, 2004). According to George and Mallery (2003) as adopted by Gliem and Gliem (2003), the rules of thumb for the interpretation of Cronbach's Alpha are: > 0.9 (Excellent), > 0.8 (Good), > 0.7(Acceptable), >0 .6 (Questionable), >0 .5(Poor), and <0 .5(Unacceptable). The Cronbach's Alpha Reliability Coefficient was determined for the study as follows:

$$
\propto=\left(\frac{k}{k-1}\right)\left\{1-\frac{1}{S^{2} T} \sum_{i=1}^{k}\left(S^{2}{ }_{\mathrm{i}}\right)\right\}
$$

Where $\propto=$ Cronbach's Alpha Reliability Coefficient

$\mathrm{k}=$ the number of items (questions)

$S^{2} T=$ the variance associated with the sum of all $\mathrm{k}$ item scores

$S^{2}{ }_{i}=$ the variance associated with item $\mathrm{i}$

Thus, a Cronbach's Alpha of 0.8901 was obtained for the study, an indication of good internal consistency of the items under study. In the ranking of the opinions, the opinion with the highest RII was ranked first while the one with the lowest RII was ranked last. A one-way Analysis of Variance (ANOVA) was used to determine whether differences in the level of understanding of the basic topics in property investment valuation between the male and female respondents are significant statistically while the Spearman's Rank-Order Correlation Model was used to determine whether the male and female respondents under study relate significantly in their opinions regarding the teaching and learning of property investment valuation in the University. 
Table 2: Demographic Characteristics of the Respondents

\begin{tabular}{|l|l|}
\hline Characteristics & Frequency \\
\hline Gender & $38(45.2 \%)$ \\
\hline Female & $46(54.8 \%)$ \\
\hline Male & $84(100 \%)$ \\
\hline Total & \multicolumn{2}{|l|}{} \\
\hline Age Group & $58(69.0 \%)$ \\
\hline $21-25$ years & $24(28.6 \%)$ \\
\hline $26-30$ years & $2(2.4 \%)$ \\
\hline $31-35$ years & $84(100 \%)$ \\
\hline Total & \multicolumn{2}{|l|}{} \\
\hline Marital Status & $6(7.1 \%)$ \\
\hline Married & $78(92.9 \%)$ \\
\hline Single & $84(100 \%)$ \\
\hline Total &
\end{tabular}

Source: Author's Field Survey 
Table 3: Respondents' Responses on their Level of Understanding of the Basic Topics in Property Investment Valuation

\begin{tabular}{|c|c|c|c|c|c|c|c|c|c|c|c|c|c|c|c|}
\hline \multirow[t]{3}{*}{ Basic Topics } & \multicolumn{15}{|c|}{ Level of Understanding } \\
\hline & \multicolumn{3}{|c|}{$\begin{array}{l}\text { Very } \\
\text { Good }\end{array}$} & \multicolumn{3}{|c|}{ Good } & \multicolumn{3}{|c|}{ Fair } & \multicolumn{3}{|c|}{ Poor } & \multicolumn{3}{|c|}{$\begin{array}{l}\text { Very } \\
\text { Poor }\end{array}$} \\
\hline & $\mathbf{M}$ & $\mathbf{F}$ & All & $\mathbf{M}$ & $\mathbf{F}$ & All & $\mathbf{M}$ & $\mathbf{F}$ & All & $\mathbf{M}$ & $\mathbf{F}$ & All & $\mathbf{M}$ & $\mathbf{F}$ & All \\
\hline $\begin{array}{l}\text { Definition of property } \\
\text { investment }\end{array}$ & 19 & 11 & 30 & 24 & 24 & 48 & 3 & 2 & 5 & - & - & - & - & - & - \\
\hline $\begin{array}{l}\text { Classification of property } \\
\text { investments }\end{array}$ & 13 & 6 & 19 & 31 & 27 & 58 & 2 & 5 & 7 & - & - & - & - & - & - \\
\hline $\begin{array}{l}\text { Characteristics of property } \\
\text { investments }\end{array}$ & 15 & 8 & 23 & 21 & 24 & 45 & 10 & 5 & 15 & - & - & - & - & - & - \\
\hline The property market & 17 & 16 & 33 & 22 & 20 & 42 & 7 & 1 & 8 & - & - & - & - & - & - \\
\hline Property market cycles & 2 & 2 & 4 & 14 & 12 & 26 & 25 & 18 & 43 & 1 & 4 & 5 & - & 1 & 1 \\
\hline $\begin{array}{l}\text { Mathematics of property } \\
\text { investment valuation }\end{array}$ & 7 & 1 & 8 & 11 & 13 & 24 & 19 & 21 & 40 & 5 & 2 & 7 & - & - & - \\
\hline $\begin{array}{l}\text { Construction of property } \\
\text { investment valuation tables }\end{array}$ & 7 & 3 & 10 & 8 & 8 & 16 & 20 & 20 & 40 & 10 & 5 & 15 & - & 2 & 2 \\
\hline $\begin{array}{l}\text { Determination of net income } \\
\text { of real properties }\end{array}$ & 10 & 4 & 14 & 18 & 17 & 35 & 15 & 14 & 29 & 2 & 2 & 4 & - & - & - \\
\hline $\begin{array}{l}\text { The Years' Purchase as an } \\
\text { Income Capitalisation Factor }\end{array}$ & 11 & 4 & 15 & 19 & 18 & 37 & 12 & 12 & 24 & 3 & 2 & 5 & - & 1 & 1 \\
\hline Theory of property yields & 8 & 3 & 11 & 14 & 15 & 29 & 22 & 14 & 36 & 2 & 4 & 6 & - & - & - \\
\hline $\begin{array}{l}\text { Conventional leasehold } \\
\text { valuation }\end{array}$ & 7 & 4 & 11 & 19 & 10 & 29 & 18 & 18 & 36 & 2 & 4 & 6 & - & - & - \\
\hline $\begin{array}{l}\text { Conventional freehold } \\
\text { valuation }\end{array}$ & 7 & 3 & 10 & 21 & 13 & 34 & 17 & 16 & 33 & - & 4 & 4 & - & - & - \\
\hline Marriage Valuation & 4 & 2 & 6 & 11 & 14 & 25 & 15 & 7 & 22 & 14 & 6 & 20 & 1 & 6 & 7 \\
\hline
\end{tabular}


Table 3 Continued: Respondents' Responses on their Level of Understanding of the Basic Topics in Property Investment Valuation

\begin{tabular}{|c|c|c|c|c|c|c|c|c|c|c|c|c|c|c|c|}
\hline \multirow[t]{3}{*}{ Basic Topics } & \multicolumn{15}{|c|}{ Level of Understanding } \\
\hline & \multicolumn{3}{|c|}{$\begin{array}{l}\text { Very } \\
\text { Good }\end{array}$} & \multicolumn{3}{|c|}{ Good } & \multicolumn{3}{|c|}{ Fair } & \multicolumn{3}{|c|}{ Poor } & \multicolumn{3}{|c|}{$\begin{array}{l}\text { Very } \\
\text { Poor }\end{array}$} \\
\hline & $\mathbf{M}$ & $\mathbf{F}$ & All & $\mathbf{M}$ & $\mathbf{F}$ & All & $\mathbf{M}$ & $\mathbf{F}$ & All & $\mathbf{M}$ & $\mathbf{F}$ & All & $\mathbf{M}$ & $\mathbf{F}$ & All \\
\hline $\begin{array}{l}\text { Statistical techniques in } \\
\text { property investment valuation }\end{array}$ & 6 & 2 & 8 & 9 & 11 & 20 & 23 & 16 & 39 & 6 & 5 & 11 & - & 1 & 1 \\
\hline Equated yield technique & 3 & 2 & 5 & 14 & 16 & 30 & 19 & 14 & 33 & 6 & 6 & 12 & 1 & - & 1 \\
\hline Real value approach & 4 & 1 & 5 & 15 & 12 & 27 & 18 & 14 & 32 & 9 & 9 & 18 & - & 1 & 1 \\
\hline Explicit DCF technique & 5 & 1 & 6 & 9 & 12 & 21 & 16 & 15 & 31 & 7 & 6 & 13 & 3 & 3 & 6 \\
\hline $\begin{array}{l}\text { Contemporary leasehold } \\
\text { valuation }\end{array}$ & 4 & 2 & 6 & 14 & 15 & 29 & 24 & 15 & 39 & 3 & 6 & 9 & - & - & - \\
\hline $\begin{array}{l}\text { Contemporary freehold } \\
\text { valuation }\end{array}$ & 5 & 1 & 6 & 12 & 18 & 30 & 24 & 12 & 36 & 2 & 7 & 9 & 1 & - & 1 \\
\hline $\begin{array}{l}\text { Hedonic modelling of } \\
\text { property investment values }\end{array}$ & 3 & 1 & 4 & 4 & 4 & 8 & 16 & 11 & 27 & 12 & 13 & 25 & 5 & 6 & 11 \\
\hline $\begin{array}{l}\text { Depreciation of property } \\
\text { investments }\end{array}$ & 6 & 4 & 10 & 20 & 21 & 41 & 16 & 10 & 26 & 4 & 2 & 6 & - & - & - \\
\hline $\begin{array}{l}\text { Computer applications in } \\
\text { property investment valuation }\end{array}$ & 5 & 6 & 11 & 11 & 7 & 18 & 14 & 11 & 25 & 8 & 9 & 17 & 4 & 3 & 7 \\
\hline
\end{tabular}

Note: M= Male Respondents' Responses; F= Female Respondents' Responses; All= Responses of all Respondents

Source: Field Survey (2010) 
Table 4: Respondents' Opinions on the Teaching and Learning of Property Investment Valuation in the University

\begin{tabular}{|c|c|c|c|c|c|c|c|c|c|c|c|c|c|c|c|}
\hline \multirow[t]{3}{*}{ Opinion } & \multicolumn{15}{|c|}{ Respondents' Responses } \\
\hline & \multicolumn{3}{|c|}{$\begin{array}{l}\text { Strongly } \\
\text { Agree }\end{array}$} & \multicolumn{3}{|c|}{ Agree } & \multicolumn{3}{|c|}{ Undecided } & \multicolumn{3}{|c|}{ Disagree } & \multicolumn{3}{|c|}{$\begin{array}{l}\text { Strongly } \\
\text { Disagree }\end{array}$} \\
\hline & $\mathbf{M}$ & $\mathbf{F}$ & All & $\mathbf{M}$ & $\mathbf{F}$ & All & $\mathbf{M}$ & $\mathbf{F}$ & All & $\mathbf{M}$ & $\mathbf{F}$ & All & $\bar{M}$ & $\mathbf{F}$ & All \\
\hline $\begin{array}{l}\text { Property investment valuation } \\
\text { is an aspect of financial } \\
\text { mathematics and should be } \\
\text { taught using mathematical } \\
\text { teaching methods }\end{array}$ & 16 & 6 & 22 & 27 & 25 & 52 & 3 & 6 & 9 & - & 1 & 1 & - & - & - \\
\hline $\begin{array}{l}\text { Quantitative skills are } \\
\text { necessary for solving property } \\
\text { investment valuation } \\
\text { problems }\end{array}$ & 17 & 10 & 27 & 22 & 26 & 48 & 6 & 2 & 8 & 1 & - & 1 & - & - & - \\
\hline $\begin{array}{l}\text { Practical exercises in the field } \\
\text { will facilitate understanding } \\
\text { of property investment } \\
\text { valuation }\end{array}$ & 34 & 31 & 65 & 10 & 5 & 15 & 2 & 2 & 4 & - & - & - & - & - & - \\
\hline $\begin{array}{l}\text { Most examples in property } \\
\text { investment valuation given by } \\
\text { lecturers in the classroom are } \\
\text { abstract }\end{array}$ & 15 & 14 & 29 & 21 & 19 & 40 & 5 & 1 & 6 & 3 & 3 & 6 & 1 & 1 & 2 \\
\hline $\begin{array}{l}\text { Property investment valuation is } \\
\text { difficult to understand }\end{array}$ & 4 & 2 & 6 & 11 & 9 & 20 & 3 & 5 & 8 & 22 & 21 & 43 & 4 & 1 & 5 \\
\hline $\begin{array}{l}\text { Lecturers with practical } \\
\text { experience teach property } \\
\text { investment valuation better }\end{array}$ & 29 & 18 & 47 & 14 & 16 & 30 & - & 3 & 3 & 1 & - & 1 & 1 & - & 1 \\
\hline $\begin{array}{l}\text { Computer software should be } \\
\text { used in the teaching of property } \\
\text { investment valuation }\end{array}$ & 23 & 19 & 42 & 12 & 10 & 22 & 9 & 9 & 18 & 1 & - & 1 & - & - & - \\
\hline
\end{tabular}

Note: $\mathrm{M}=$ Male Respondents' Responses; $\mathrm{F}=$ Female Respondents' Responses; All= Responses of all Respondents

Source: Field Survey (2010) 
Table 4 Continued: Respondents' Opinions on the Teaching and Learning of Property Investment Valuation in the University

\begin{tabular}{|c|c|c|c|c|c|c|c|c|c|c|c|c|c|c|c|}
\hline \multirow[t]{3}{*}{ Opinion } & \multicolumn{15}{|c|}{ Respondents' Responses } \\
\hline & \multicolumn{3}{|c|}{$\begin{array}{c}\text { Strongly } \\
\text { Agree }\end{array}$} & \multicolumn{3}{|c|}{ Agree } & \multicolumn{3}{|c|}{ Undecided } & \multicolumn{3}{|c|}{ Disagree } & \multicolumn{3}{|c|}{$\begin{array}{l}\text { Strongly } \\
\text { Disagree }\end{array}$} \\
\hline & $\mathbf{M}$ & $\mathbf{F}$ & All & $\mathbf{M}$ & $\mathbf{F}$ & All & $\mathbf{M}$ & $\mathbf{F}$ & All & $\mathbf{M}$ & $\mathbf{F}$ & All & $\mathbf{M}$ & $\mathbf{F}$ & All \\
\hline $\begin{array}{l}\text { Students should be given real } \\
\text { live problems in property } \\
\text { investment valuation to solve } \\
\text { in the classroom }\end{array}$ & 28 & 19 & 47 & 15 & 14 & 29 & 3 & 4 & 7 & - & 1 & 1 & - & - & - \\
\hline $\begin{array}{l}\text { Only lecturers with a } \\
\text { minimum of Masters degree } \\
\text { and professional } \\
\text { qualifications should teach } \\
\text { property investment valuation }\end{array}$ & 20 & 22 & 42 & 14 & 9 & 23 & 6 & 4 & 10 & 2 & 3 & 5 & 2 & - & 2 \\
\hline $\begin{array}{l}\text { Property investment valuation } \\
\text { should be taught together with } \\
\text { valuation of stocks and shares }\end{array}$ & 15 & 10 & 25 & 21 & 17 & 38 & 5 & 7 & 12 & 1 & 4 & 5 & 2 & - & 2 \\
\hline
\end{tabular}

Note: M= Male Respondents' Responses; F= Female Respondents’ Responses; All= Responses of all Respondents

Source: Field Survey (2010) 


\section{Results and Discussion}

Respondents strongly agreed that practical exercises in the field will facilitate understanding of property investment valuation. This opinion was ranked first by the respondents with a RII of 0.95 as presented in Table 6. Similarly, respondents also agreed that lecturers with practical experience teach property investment valuation better. This opinion was ranked second by the respondents with a RII of 0.90 . In terms of the consensus opinion, the respondents agreed on all the opinions, but were undecided on the opinion that property investment valuation is difficult to understand. This opinion was ranked last by the respondents with a RII of 0.55. Analysis of Variance (ANOVA) in the level of understanding of the basic topics in property investment valuation between the male and female respondents produced an F-ratio of 0.53 at p-value greater than 0.05 as presented in Table 7 . This implies that although there are differences in the level of understanding of the basic topics in property investment valuation between the male and female respondents, such differences are not significant statistically. The correlation analysis of opinions of male and female respondents regarding the teaching and learning of property investment valuation in the University produced a strong positive correlation coefficient of 0.81 at p-value less than 0.05 . This was found to be significant at both 0.05 and 0.01 levels as the p-value is 0.0049 (2-tailed) as presented in Table 8. The implication of this is that, the male and female respondents under study relate significantly in their opinions regarding the teaching and learning of property investment valuation in the University. 
Table 5: Respondents' Overall Level of Understanding of the Basic Topics in Property Investment Valuation

\begin{tabular}{|l|c|c|c|}
\hline \multicolumn{1}{|c|}{ Basic Topics } & \multicolumn{2}{c|}{ Mean } & All \\
\cline { 2 - 4 } & Male & Female & 4.30 \\
\hline Definition of property investment & 4.35 & 4.24 & 4.14 \\
\hline Classification of property investments & 4.24 & 4.03 & 4.10 \\
\hline Characteristics of property investments & 4.11 & 4.08 & 4.30 \\
\hline The property market & 4.22 & 4.41 & 3.34 \\
\hline Property market cycles & 3.40 & 3.27 & 3.42 \\
\hline $\begin{array}{l}\text { Mathematics of property investment } \\
\text { valuation }\end{array}$ & 3.17 & 3.35 & 3.20 \\
\hline $\begin{array}{l}\text { Construction of property investment } \\
\text { valuation tables }\end{array}$ & 3.27 & 3.13 & 3.72 \\
\hline $\begin{array}{l}\text { Determination of net income of real } \\
\text { properties }\end{array}$ & 3.80 & 3.62 & 3.73 \\
\hline $\begin{array}{l}\text { The Years' Purchase as an Income } \\
\text { Capitalisation Factor }\end{array}$ & 3.84 & 3.59 & 3.55 \\
\hline Theory of property yields & 3.61 & 3.47 & 3.55 \\
\hline Conventional leasehold valuation & 3.67 & 3.39 & 3.62 \\
\hline Conventional freehold valuation & 3.78 & 3.42 & 3.04 \\
\hline Marriage Valuation & 3.04 & 3.00 & 3.29 \\
\hline $\begin{array}{l}\text { Statistical techniques in property } \\
\text { investment valuation }\end{array}$ & 3.34 & 3.23 & 3.32 \\
\hline Equated yield technique & 3.28 & 3.37 & 3.20 \\
\hline Real value approach & 3.30 & 3.08 & 3.10 \\
\hline Explicit DCF technique & 3.42 & 3.05 & 3.34 \\
\hline Contemporary leasehold valuation & 3.12 & 3.34 & 3.46 \\
\hline Contemporary freehold valuation & & 3.11 & \\
\hline $\begin{array}{l}\text { Hedonic modelling of property } \\
\text { investment values }\end{array}$ & & & \\
\hline Depreciation of property investments & & & \\
\hline $\begin{array}{l}\text { Computer applications in property } \\
\text { investment valuation }\end{array}$ & & & \\
\hline Source: Computed from Data & & & \\
\hline
\end{tabular}

Source: Computed from Data in Table 3 
Table 6: Respondents' Consensus Opinion on the Teaching and Learning of Property Investment Valuation in the University

\begin{tabular}{|c|c|c|c|c|c|c|}
\hline \multirow[t]{2}{*}{ Opinion } & \multicolumn{3}{|c|}{ Mean } & \multirow{2}{*}{$\begin{array}{c}\text { Respondents' } \\
\text { Consensus } \\
\text { Opinion } \\
\end{array}$} & \multirow{2}{*}{$\begin{array}{c}\text { Relative } \\
\text { Importance } \\
\text { Index } \\
\end{array}$} & \multirow[t]{2}{*}{ Rank } \\
\hline & Male & Female & All & & & \\
\hline $\begin{array}{l}\text { Property investment valuation } \\
\text { is an aspect of financial } \\
\text { mathematics and should be } \\
\text { taught using mathematical } \\
\text { teaching methods }\end{array}$ & 4.28 & 3.95 & 4.13 & Agree & 0.83 & 7 \\
\hline $\begin{array}{l}\text { Quantitative skills are } \\
\text { necessary for solving property } \\
\text { investment valuation problems }\end{array}$ & 4.20 & 4.21 & 4.20 & Agree & 0.84 & 5 \\
\hline $\begin{array}{l}\text { Practical exercises in the field } \\
\text { will facilitate understanding of } \\
\text { property investment valuation }\end{array}$ & 4.70 & 4.76 & 4.73 & $\begin{array}{c}\text { Strongly } \\
\text { Agree }\end{array}$ & 0.95 & 1 \\
\hline $\begin{array}{l}\text { Most examples in property } \\
\text { investment valuation given by } \\
\text { lecturers in the classroom are } \\
\text { abstract }\end{array}$ & 4.02 & 4.11 & 4.06 & Agree & 0.81 & 8 \\
\hline $\begin{array}{l}\text { Property investment valuation } \\
\text { is difficult to understand }\end{array}$ & 2.75 & 2.74 & 2.74 & Undecided & 0.55 & 10 \\
\hline $\begin{array}{l}\text { Lecturers with practical } \\
\text { experience teach property } \\
\text { investment valuation better }\end{array}$ & 4.53 & 4.41 & 4.48 & Agree & 0.90 & 2 \\
\hline $\begin{array}{l}\text { Computer software should be } \\
\text { used in the teaching of property } \\
\text { investment valuation }\end{array}$ & 4.27 & 4.26 & 4.27 & Agree & 0.85 & 4 \\
\hline $\begin{array}{l}\text { Students should be given real } \\
\text { live problems in property } \\
\text { investment valuation to solve in } \\
\text { the classroom }\end{array}$ & 4.54 & 4.34 & 4.45 & Agree & 0.89 & 3 \\
\hline $\begin{array}{l}\text { Only lecturers with a minimum } \\
\text { of Masters degree and } \\
\text { professional qualifications } \\
\text { should teach property } \\
\text { investment valuation }\end{array}$ & 4.09 & 4.32 & 4.20 & Agree & 0.84 & 5 \\
\hline $\begin{array}{l}\text { Property investment valuation } \\
\text { should be taught together with } \\
\text { valuation of stocks and shares }\end{array}$ & 4.05 & 3.87 & 3.96 & Agree & 0.79 & 9 \\
\hline
\end{tabular}

Source: Computed from Data in Table 4 
Table 7: Result of the Analysis of Variance in the level of understanding of the basic topics in property investment valuation between the male and female respondents under study

\begin{tabular}{|l|r|r|r|r|c|}
\hline \multicolumn{1}{|c|}{ Source of variation } & \multicolumn{1}{c|}{$\begin{array}{c}\text { Sum } \\
\text { squares }\end{array}$} & DF & $\begin{array}{c}\text { Mean } \\
\text { square }\end{array}$ & F statistic & \multicolumn{1}{c|}{$\mathrm{p}$} \\
\hline Groups & 0.102 & 1 & 0.102 & 0.53 & 0.4712 \\
\hline Residual & 8.113 & 42 & 0.193 & & \\
\hline Total & 8.215 & 43 & & & \\
\hline
\end{tabular}

Source: Computed from Data in Table 3

Table 8: Result of correlation analysis of opinions of male and female respondents regarding the teaching and learning of property investment valuation in the University

\begin{tabular}{|l|r|l|}
\hline rs statistic & 0.81 & \\
\hline 95\% CI & 0.36 & to 0.95 \\
\hline t statistic & 3.85 & \\
\hline DF & 8 & \\
\hline 2-tailed p & 0.0049 & \\
\hline
\end{tabular}

Source: Computed from Data in Table 4

\section{Findings}

Majority of the respondents strongly hold the opinion that practical exercises in the field will facilitate understanding of property investment valuation. Furthermore, other opinions agreed by the respondents are that property investment valuation is an aspect of financial mathematics and should be taught using mathematical teaching methods, most examples in property investment valuation given by lecturers in the classroom are abstract, lecturers with practical experience teach property investment valuation better, computer software should be used in the teaching of property investment valuation, students should be given real live problems in property investment valuation to solve in the classroom, only lecturers with a minimum of Masters degree and professional qualifications should teach property investment valuation, and property investment valuation should be taught together with valuation of stocks and shares. However, the respondents were undecided on the opinion that property investment valuation is difficult to understand. Although there are differences in the level of understanding of the basic topics in property investment valuation between the male and female respondents, such differences are not significant statistically as the Analysis of Variance (ANOVA) in the level of understanding of the basic topics in property investment valuation between the male and female respondents produced an F-ratio of 0.53 at p-value greater than 0.05 . 


\section{Conclusion}

Based on the findings of the study, there is need for practical-based property investment valuation curriculum in Nigeria, in which property investment valuation is taught together with valuation of financial assets with real time problem-based learning. This is necessary for the development of skills in comparative investment appraisal and the training of property valuers for impeccable valuation of property investments in the country. In conclusion, there is need for the introduction of more field exercises into the current property investment valuation curriculum of tertiary institutions in Nigeria. Such initiative will facilitate the development of creative, innovative and practically-competent human resources for the accurate valuation of property investments in the country.

\section{References}

Ake, C. (1989), Keynote Address, In Ogbuagu, S. C. (Ed.), Strategy for National Development in Nigeria, Calabar: University of Calabar Press.

Baum, A. and Mackmin, D. (1989), The Income Approach to Property Valuation (3e), London: Routledge.

Cronbach, L. J. (1951), Coefficient Alpha and the Internal Structure of Tests, Psychometrika. 16: pp. 297-334.

Cronbach, L. J., Gleser, G. C., Nanda, H., and Rajaratnam, N. (1972), The Dependability of Behavioural Measurements, New York: Wiley.

Cronbach, L. J. (2004), "My Current thoughts on Coefficient Alpha and successor procedures", Educational and Psychological Measurement. 64: 391.

Dawodu, A. M. (n.d), "Human Resources Development Challenges in the face of the Current Global Economic Meltdown: The Nigeria Perspective", Lagos: Daam \& Associates Nigeria Ltd.

George, D., and Mallery, P. (2003), SPSS for Windows step by step: A simple guide and reference. (4e), Boston: Allyn \& Bacon.

Gliem, J. A. and Gliem, R.R. (2003), Calculating, interpreting, and reporting Cronbach's Alpha reliability coefficient for likert-type scales. Paper Presented at the Midwest Research-to- Practice Conference in Adult, Continuing, and Community Education held at the Ohio State University, Columbus, Ohio, October 8-10.

Grabowski, R. and Shields, M. (1996), Development Economics, New York: Blackwell Publishers.

Harbison, F. (1973), Human Resources as the Wealth of the Nations, New York: Oxford University Press.

Millington, A.F. (1982), An Introduction to Property Valuation (2e). London: Estates Gazette.

Ogunleye-Adetona, C.I. (2010), Human Resources and Economic Development in Nigeria. Journal of Sustainable Development in Africa.12 (3), pp. 204-211. 
Peters, A. A. (2011), Population and Human Resource Development in Nigeria, Paper presented to Course 20 participants at the National Defence College, Abuja on 5th October.

UNDP (2010), Human Capital Development Index Rankings. Retrieved from http://www.indr.undp.org/en/reports/global.html on 2nd July, 2011.

Work Bank (1974), Options for Long-Term Development. Baltimore: The John Hopkins University Press. 